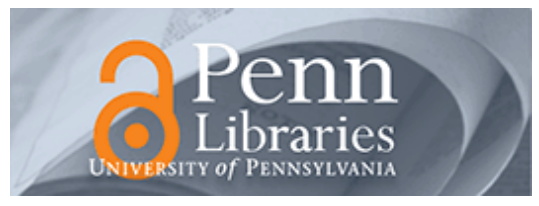

University of Pennsylvania ScholarlyCommons

\title{
Writing Culture; Inscribing Lives: A Reflective Treatise on the Burden of Representation in Native Research
}

Ameena Ghaffar-Kucher

University of Pennsylvania, agk@gse.upenn.edu

Follow this and additional works at: https://repository.upenn.edu/gse_pubs

Part of the Social and Cultural Anthropology Commons, and the Sociology of Culture Commons

\section{Recommended Citation}

Ghaffar-Kucher, A. (2014). Writing Culture; Inscribing Lives: A Reflective Treatise on the Burden of Representation in Native Research. International Journal of Qualitative Studies in Education, 1-17. http://dx.doi.org/10.1080/09518398.2014.974720

This paper is posted at ScholarlyCommons. https://repository.upenn.edu/gse_pubs/277

For more information, please contact repository@pobox.upenn.edu. 


\title{
Writing Culture; Inscribing Lives: A Reflective Treatise on the Burden of Representation in Native Research
}

\author{
Abstract \\ This paper complicates the contested assumptions surrounding native research by exploring the burden \\ of representation placed on native researchers because they are seen as insiders. This particular issue of \\ representation is important for native researchers to consider, especially in instances where the research \\ is on an understudied or politically charged group, because of the ways in which the socio-political \\ climate influences both the telling and the reading of such research. Drawing on the author's personal \\ struggles as a Pakistani researcher conducting ethnographic research with Pakistani immigrants in the \\ United States in the post-9/11 climate, this paper explores and critiques the role of the native researcher \\ and the issues involved with representing understudied groups. Specifically, the paper focuses on \\ authenticity, positionality, audience, and accountability. Thus, the paper is a call for researchers to be \\ more reflective and to think more deeply about their positionality and its impact on the various \\ constituents as they research and write. To encourage such reflexivity, the article provides a set of \\ questions for researchers to consider at different stages of the research and writing process.
}

\section{Keywords}

insider research, native research, immigrants, representation, ethnography, 9/11

Disciplines

Social and Cultural Anthropology | Sociology of Culture 
International Journal of Qualitative Studies in Education

\section{Writing culture; inscribing lives: a reflective treatise on the burden of representation in native research \\ Ameena Ghaffar-Kucher \\ University of Pennsylvania}

DOI:10.1080/09518398.2014.974720

Published online: 21 Nov 2014 
Writing culture; inscribing lives: A reflective treatise on the burden of representation in native research

ABSTRACT: This paper complicates the contested assumptions surrounding native research by exploring the burden of representation placed on native researchers because they are seen as insiders. This particular issue of representation is important for native researchers to consider, especially in instances where the research is on an understudied or politically charged group, because of the ways in which the socio-political climate influences both the telling and the reading of such research. Drawing on the author's personal struggles as a Pakistani researcher conducting ethnographic research with Pakistani immigrants in the United States in the post-9/11 climate, this paper explores and critiques the role of the native researcher and the issues involved with representing understudied groups. Specifically, the paper focuses on authenticity, positionality, audience, and accountability. Thus the paper is a call for researchers to be more reflective and to think more deeply about their positionality and its impact on the various constituents as they research and write. To encourage such reflexivity, the article provides a set of questions for researchers to consider at different stages of the research and writing process.

Keywords: insider research, native research; immigrants; representation; ethnography; $9 / 11$ 


\section{Writing culture; inscribing livesi: A reflective treatise on the burden of representation in native research}

A few years ago, I was presenting my research on Pakistani-American ${ }^{\mathrm{ii}}$ youth to a diverse group of educational scholars. During the discussion, a member of the academic audience commented, "I am always suspicious of people who study themselves." The white, male audience member was alluding to the fact that I was a Pakistani researcher conducting research on Pakistani immigrants - what is known as native research - and was suggesting that I could not possibly be objective in my research. The assumption here was that because I shared the national background of my participants, I was an insider and therefore biased in my observations. Although this desire for objective and bias-free research remains the gold standard for those who maintain more positivist orientations to research, it is no longer the perspective of the majority (at least in qualitative research). Quite to the contrary, with the postmodern turn in qualitative research (Lincoln, Lynham, \& Guba, 2011), the doors to multiple ways of knowing and subjectivities have been opened; consequently, the native researcher is considered to have a more nuanced understanding of the community and therefore an important voice that needs to be heard (Foley, Levinson, \& Hurtig, 2000). However, this more positive reading of native research is as problematic as the negative reading illustrated in the opening vignette.

In this article, I complicate a longstanding discussion regarding native research by raising the issue of the "burden of representation" (a term I borrow from visual and cultural studies) that is often placed on the shoulders of so-called native researchers. In other words, even if a native researcher acknowledges that her knowledge of her native community is partial at best, she is seen as an expert on the community and bears the burden of representing the community. This burden is placed on the native researcher both by the community under study 
and by those in the academy who value the "insider" perspective. Just as importantly, it is also often the researcher herself who embraces the burden in attempt to empower or do justice to the community in question. The desire to embrace the burden of representation is especially acute when the research is on an understudied community or is politically charged because of the paucity of research or polarizing viewpoints that exist in that realm. Such was the case of my research among Pakistani Muslim immigrants in the post-9/11 era.

Continuing the anthropological tradition of problematizing the notion of what it means to be an "insider" because of one's "native status," in this article I discuss the lessons I learned from conducting what is considered "native research." Like many others before me (DelgadoGaitan, 1993; Narayan, 1993), I argue that just because one shares a national or ethnic background with one's participants, this common attribute does not directly translate into insider status, and this assumption that one is an insider has serious implications for one's research design. I push on the issue of native research further by bringing into the conversation the notion of the burden of representation, which takes into consideration not only issues of representation but also the positionality of the native researcher - both in the sense of how one positions oneself and how one is positioned by others, and the implications of this positioning for the reading and writing of the research itself. I conclude by offering a set of questions for qualitative researchers to consider as we think about our work in order to encourage more researcher reflexivity and more accountability to our various communities and constituents (i.e., our participants, the academy, and a wider audience).

\section{Brown Skin, White Privilege}

This article is based on my experiences as a Pakistani researcher conducting my dissertation research with Pakistani-American youth in New York City. My multi-sited ethnographic study spanned several months between February 2004 and January 2008. I 
explored the ways in which mostly working-class Pakistani-American youth negotiated the expectations of various groups and institutions - namely, family, school, and ethnic community - in a post-9/11 context. In reflecting on my own identity and positionality, I recognize that although I am brown skinned, in many ways, my social, cultural, and consumer capital actually give me certain white [read "middle-class"] privileges. At times during this research - and certainly as I wrote it up and presented my findings - I have felt like an imposter telling a story about a group of people for whom it is assumed that I have insider knowledge because of our shared national origins. However, as I have learned through this very research, our shared national origins gave me valuable background knowledge and a degree of entry into the community but little more. Therefore, in this paper, I reflect on how I navigated the evershifting sands of insider and outsider statuses with Pakistani-American youth - a group with whom I share national, ethnic, and religious identities - and the implications of this for my research.

I begin by exploring the notion of representation, followed by an examination of how native research is conceptualized within the larger research discourse. Next, I focus on three important concepts: authenticity - what makes a native, native; positionality - how one positions oneself and one's research, and how one is positioned by others; and audience and accountability - the importance of acknowledging and understanding those for whom one is writing. In the final section, I provide three sets of questions for researchers - both novice and experienced - to consider throughout the research period, beginning with conception of the project all the way to dissemination of the results. In exploring these aspects of native research, I expose problematic assumptions held by native researchers; raise issues to consider around representation, especially for research that is politically charged; and argue for greater attention to researcher reflexivity, irrespective of researcher background and one's ontological position. 


\section{Representation: From Crisis to Burden}

Qualitative researchers are well versed in the idea that research is never simply about the participants of a study. They acknowledge that the study is as much about the researcher and the interpretations she brings to the table as it is the people being studied. Regarding ethnographic research in particular, Denzin and Lincoln (1998) posit,

The false division between the personal and the ethnographic self rests on the assumption that it is possible for an author to write a text that does not bear the traces of its author. Of course, this is impossible.... All texts are personal statements. (p. 413)

Here, Denzin and Lincoln essentially argue that we cannot separate who we are from what we observe or what we write. This is just one aspect of what is known as the "crisis of representation," that is, the inability of qualitative researchers to adequately represent the "lived experiences" of their participants in textual form (Denzin \& Lincoln, 1994, p. 18).

I take this idea one step further by arguing that for native researchers, the crisis of representation faced by qualitative researchers is compounded by three additional issues: First, the question of whether the native researcher is really an insider who has a deeper understanding of the community under study and, hence, is able to "represent" the community in a more nuanced way. Second, when the research is on an issue that is politically charged or hyper-present in public discourse (for example, Muslim immigrant communities), the native researcher must take extra care in how she represents the community, as the research will be read differently by different audiences (i.e., depending on the reader's politics and points of view on the issue); it can therefore have grave implications for the community in question. Third, the native researcher carries the additional burden of representation because, for some 
audiences, she is seen as an insider and, therefore, is expected to be able to represent the community more adequately than a non-native. The notion of the burden of representation comes from the visual arts, literature, and cultural studies; I find it a useful concept for thinking about how "native" (read: non-white) researchers position themselves and their research, and how they are positioned by others.

In his book, The Burden of Representation: Essays on Photographies and Histories (1988), John Tagg draws on post-structuralism, cultural studies, and semiotics to argue that photographs are not neutral visual representations but are instead the product of the power relations that play a role in modern social regulation. If we consider a researcher as analogous to a photographer, then what Tagg is pushing us to consider is how the histories and politics around the (re)presentation of a particular moment in time influences the picture we create with our words. Tagg contends,

Like the state, the camera is never neutral. The representations it produces are highly coded, and the power it wields is never its own. As a means of record, it arrives on the scene vested with a particular authority to arrest, picture and transform daily life; a power to see and record; a power of surveillance that effects a complete reversal of the political axis of representation.... This is not the power of the camera but the power of the apparatuses of the local state, which deploy it and guarantee the authority of the images it constructs to stand as evidence or to register a truth. (pp. 63-64) Representation, then, is always politically and historically situated. When the person capturing the moment is identified as a member of the group, the issue of representation becomes all the more complicated. Although such a situation is as an opportunity to be the subject of one's own representation rather than the object of someone else's (Hall, 1989), this experience can be 
fraught with tension, as exemplified by Stuart Hall's examination of black film makers.

In his seminal piece, “New Ethnicities" (1988), Hall examines the tensions inherent in what he calls the "relations of representation" (p. 443). Using the example of black film makers, Hall argues that representation can be considered not only a process of artistic portrayal (e.g., making a film), but also a sense of speaking as a representative of and for the black community. Because these opportunities to "come into representation" are so limited, the filmmakers assume the burden of representing and speaking for the black community, and of "representing" blacks with positive imagery. At the same time, they struggle with the notion that their work is seen as representing all blacks. This burden of representation is heightened when the work in question (be it film or research) is on a political or racialized subject, and it is heightened further when the researcher is one of only a few voices in that particular realm. On the one hand, as Baldonado (1996) points out, "Since there are so few images, negative ones can have devastating affects on the real lives of marginalized people" (\9). On the other hand, when representations do not fit with mainstream representations, then the "'subaltern's' act of representation is not heard" ( $\$ 11)$. Thus, the audience's reading of a film or text can be influenced by the identity of the filmmaker, writer, or researcher but also by politics and history. As such, the act of representation is replete with tension. This tension is especially apparent in instances of politically charged research, where, depending on the particular audience's own views of the politics that the research in a sense represents, the native researcher's voice can either be amplified or rendered mute. Take, for example, the topic of immigration. Despite the fact the United States is a nation of immigrants, new immigrants (particularly non-white immigrants) are seen as an economic menace, where the narrative is that these immigrants steal jobs from Americans and stretch the social support system. Since the events of 9/11, we see another discourse come to the fore (though it has always been bubbling just below the surface) 
in which immigrants are not just an economic problem but also a security threat (here, brown young men, in particular, are potential terrorists). Thus the current anti-immigration and Islamophobic zeitgeist renders any research on immigrants - particularly "brown folk" and Muslim immigrants - as somewhat suspect, especially when the researcher shares the same background as her participants.

In my own research with Pakistani immigrant youth, I struggled to find ways to represent the Pakistani community without vilifying or romanticizing them. Foley (2008) alludes to this tension when he argues that the "new 'native ethnographers' are faced with a difficult task of essentializing cultural differences and traditions without romanticizing and glorifying their subjects in the way some race-conscious [w] hite scholars have" (p. 28). Foley's point resonates with me because of the dilemma I faced as a native researcher: I wanted to be honest in my work, which reflected the complexity of Pakistani diaspora - just like any other community - but I worried that because of increasing anti-Muslim and sometimes antiPakistani sentiments, people would use aspects of my research as evidence of the community's problems and ignore the parts that did not fit into the pictures they had in their minds. In other words, I worried that my work would be read in a way that would be a disservice to the community, for example by framing them as narrow minded, overly religious and thus missing the nuances in my argument (see, for example, Ghaffar-Kucher, 2014). At some level, my concern can be applied to all research, but, returning to Baldonado's point, when there are so few voices out there, what one says and how it is perceived can have great ramifications for the community in question. I knew that those who felt that I was "biased" in my observations (like the audience member in the opening vignette) could potentially discredit or simply ignore my work, and therefore my attempt to highlight the issues in the community would be in vain simply because I was seen as a native researcher. But what exactly is native research, and what 
makes the native researcher, native? I turn to these issues next.

\section{Conceptualizing and Situating Native Research}

Qualitative researchers have long recognized the importance of researcher identity. Both novice and experienced researchers increasingly discuss their identities in relation to their participants in terms of their race, ethnicity, nationality, and language. This reflexivity in terms of one's own identity is especially common among those who consider themselves insiders or native researchers. This is partially a reaction to the ways in which native researchers have been held to higher standards of objectivity, given the assumption that a native researcher is an "insider" and hence would have more biases, as I will describe below. Ethnographers, in particular, seem to be fascinated by the notion of native research and have written a fair amount about the promises and pitfalls of such research (Brayboy, 2000; Collins, 2000; Delgado-Bernal, 1998; Narayan, 1993; Ong, 1995; Villanas,1996).

In its most uncritical form, the native researcher is one who shares the ethnic, national, or racial markers with that of the community members under study. Native research is thus considered research from an emic or insider's point of view. Consequently, perspectives regarding native research seem to fall into two general categories: On the one hand, native researchers are lauded for decolonizing research and bringing a new voice and perspective to the table; this is especially true in cultural anthropology, which has traditionally been a discipline in which white men and women go out into the field to learn about the usually darker-skinned cultural other. In an extensive literature review on the subject, Foley, Levinson, and Hurtig (2000) contend, "ethnic researchers are among the most visible and important insider ethnographers to have arrived on the intellectual scene" (p. 37). Their perspective 
suggests that such "insider" ethnographers have greater shared knowledge to begin with, which lessens any divisions that the researcher may need to bridge (p. 41).

On the other hand, some researchers with more positivist ontologies are skeptical of native research. In particular, they criticize native researchers' claims that their identity and positionality might make them more astute observers (as Foley and colleagues contend). Instead, they argue that a researcher cannot be objective about her own group because she cannot gain enough distance from her community, thus compromising "objectivity" (if objectivity is even possible in research). Clyde Kluckhohn's (1949) famous analogy illustrates this claim: “It would hardly be the fish that would discover the existence of water" (p. 11). Kluckhohn suggested that only someone from a different perspective-perhaps looking from outside-would be able to "see" the water. Similarly, Kirstin Hastrup (1995) denies the very possibility of native anthropology, claiming that it is a "contradiction in terms" (p. 159). She argues, "There is no way in which one can simultaneously speak from a native and an anthropological position. It is logically impossible to speak from an inside and an outside position at the same time" (p. 159). (Interestingly, white researchers studying white populations do not seem to be questioned in this way. This may be because whites often feel they do not have "ethnicity" and are "cultureless," hence there is no ground from which to be biased. See Perry, 2001, for a discussion on whites' cultureless identities).

Both perspectives on native researchers would assume that because I share the national origin of the majority of the participants in my study, my participants and I can be grouped under the category of Pakistani or as having Pakistani roots, and that this shared categorization makes me an insider. For those who are more positively inclined towards native research, my supposed nativeness would make my insights more astute (and hence they are more likely to place the burden of representation on my shoulders); for those who are more negatively 
inclined toward native research, my supposed nativeness would make my insights more questionable (and hence more likely to sway me to take on the burden of representation myself as a defensive reaction). Assumptions about my nativeness, however, do not take into consideration differences in age, language, ethnicity, religion, gender, sexual orientation, education, regional differences and, most important to my study, socioeconomic class. Simply sharing a national identity - and even some other attributes like language, religion, and ethnicity - does not immediately grant a native researcher insider status. One's positionality as a native researcher has grave implications for research design, what one writes, and how one's writing is perceived. Delgado-Gaitan (1993) acknowledges the unstable position of the native researcher when she explains that having an ethnic background in common with one's participants does not necessarily make the researcher more astute; in fact "[ethnic] researchers often hold misperceptions about participants' feelings, values, and practices based on influences, such as assumed cultural knowledge" (p. 291).

In her influential article "How native is a 'native' anthropologist?" (1993), Kirin Narayan laments that critiques of what insiderness or nativeness even mean have not been adequately integrated into the way native anthropologists are viewed in the discipline of anthropology in particular (p. 671). Rather than posit a dichotomy of native and non-native, Narayan suggests that each researcher be viewed in terms of "shifting identifications in a field of interpenetrating communities and power relations" (p. 671); in other words, our connections with our participants are many and constantly changing, and these fluid connections take precedence over the cultural identity associated with insider status (p. 673). Issues of interrelated communities and power are especially relevant in politicized fields, such as immigrant research. It is one thing for native researchers to go "home" to study their native communities; it is quite another to study these communities in an immigrant situation, particularly since immigration is 
a hotly contested topic and the audience that will consume this information is in the same location as those under study. I wish to draw on the conversation that Narayan and others have taken up in the discipline of anthropology and situate it in the broader methodological field of qualitative research, focusing specifically on immigration research because it is such a politicized field. In an attempt to conceptualize native research, I frame my discussion around the issue of authenticity.

\section{What Makes the Native a "Native"? Questioning (My) Authenticity}

Increasingly, "native researchers" themselves are writing about what it means to be a native researcher. As Jacobs-Huey (2002) playfully writes, “The natives are gazing and talking back" (p. 792). Scholars who have explored what it means to be a native researcher and its implications include Lila Abu-Lughod (1991), Kirin Narayan (1993), Sofia Villanas (1996), and Bryan Brayboy (2000). As I have already alluded to Narayan's concerns earlier in the paper, here I want to highlight issues that Abu-Lughod, Villanas, and Brayboy discuss. In Writing against culture (1991), Abu-Lughod identifies dilemmas that native, "halfie," and feminist anthropologists face. The most salient of these dilemmas are the multiple audiences that such researchers speak to and the need to shift between "speaking 'for' and speaking 'from'" a particular community. Villanas (1996) alerts us to a different kind of dilemma. She is concerned with what happens when "members of low-status and marginalized groups become universitysanctioned 'native' ethnographers of their own communities"(p. 712). By framing her paper around this question, Villanas is interested in understanding how native (in this case Chicana) ethnographers "mediate and complicate" their privilege, and the ways in which such researchers are "situated in oppressive structures" (p. 716). Finally, Brayboy reflects on how researchers from indigenous cultures can balance their identities as academics while 
simultaneously balancing their identities and ways of being as indigenous people. He navigates the complicated insider/outsider terrain as a Native American researcher returning to study his own community - a community where he has long-standing relationships and history (what one would call "insider" research). Here, he examines issues around methodologies that might be at odds with indigenous cultures. I take a slightly different vantage point from Abu-Lughod, Villanas, and Brayboy, since my "coming to be" a native researcher took a different path, as I describe below.

Within the field of education, there is a growing cohort of scholars like Villanas who are from minoritized immigrant groups who were raised in the United States and are now studying their own immigrant groups; this is especially the case of studies by and of Latinos (see Delgado-Gaitan, 1993; Lopez, 2002; Mendoza-Denton, 2008; Stanton-Salazar, 2001; Valenzuela, 1999; and Villanas, 2001), and increasingly includes other groups, such as scholars of South- and East-Asian heritage (see for example Shankar, 2008; Ngo, 2010). There is also the group sometimes referred to as "halfie-researchers," who are of mixed heritage (specifically, white and that of "color") who study their "darker halves" from an immigrant perspective (see Abu El-Haj, 2007). Finally, there is the growing inverse of classic anthropology, with natives from "there" coming "here" as adults and eventually studying their own native diaspora (see Maira, 2002, 2009; Zhou, 1992). I include myself in this last group. Like a number of my participants, I was born in Pakistan and am not a U.S. citizen. Like almost all of the participants in my ethnographic research, I am Muslim. Like some of my participants, Urdu is my mother tongue. But beyond these three major commonalities, we did not have all that much in common. So why is it that I am seen as a native insider? Is it the color of my hair and skin, or the language I speak? Is it my heritage, or my visa status? Could I still be considered a native insider if I did not speak the language of my participants but shared a national background, or vice versa? And 
when and how does this understanding of "nativeness" or "insiderness" matter? Native researchers are inclined to assume too quickly that they are insiders to a community because of their shared nationality or ethnicity. Like Narayan and others, I believe that the native/nonnative dichotomy is a false one - that the nativeness of a researcher falls on a continuum, and that even within the continuum there is constant shifting. Thus to talk about oneself as a native insider is problematic if one does not consider the ways in which these questions matter and what ramifications they have on the final product - the dissertation, book, article, chapter, or opinion piece that the native researcher writes.

During my research, I presented myself as a Pakistani (which is how I typically identify myself). I entered my study with the idea that I was an insider: I have a Pakistani passport, I had lived a number of years in Pakistan and now lived in the United States, and I thought I knew what it meant to be Pakistani in the United States; hence, while I acknowledged that I was an "outsider" in the sense that I did not live in the community I was studying, I imagined that I knew the community simply because we were all Pakistani. I also assumed that gaining access would be much easier for me than for a non-Pakistani. And, certainly, when it came to interacting with non-Pakistani gatekeepers at the various sites, I was seen as Pakistani and an insider to the Pakistani community. Based on the nationality I shared with the participants and my knowledge of the language, people assumed that I knew the community I was studying. This immediate acceptance that I was a native insider was not just the case with school personnel that I engaged with, but, more importantly, with members of the academy - my dissertation committee and my university's Institutional Review Board. These individuals saw my nativeness as an asset and it was assumed that the picture that I would capture with my research would have a degree of authenticity - indeed, it would be research from an emic or insider's perspective; insights that non-natives would not be privy to. Their assumption was not 
surprising since they had limited knowledge about the population I was getting ready to work with. Thus the seemingly fixed nature of nativeness (as a reflection of authenticity) perhaps enhances the burden of representation for native researchers and researchers of color.

Upon entering the field, I soon realized that I was not quite the insider I thought I was. The Pakistani immigrant girls and boys pointed out that I was "different." Though they did not question my Pakistani roots, they did not seem to think I was an authentic Pakistani. Some of the issues they brought up were seemingly superficial. For example, the youth would comment on my short hair and western-style clothes, which they saw as signs of "modern-ness"; in their view, this made my authenticity as a Pakistani questionable. For this group of working-class Pakistani-Americans, authenticity was somewhat essentialized to being religious and traditional - and certainly not an independent, working woman. After they discovered that my husband was white, my authenticity as a Pakistani was put up for further scrutiny. While these issues may seem superficial, they were important because they marked me as an outsider to the community and they complicate what is meant by "native research". The student's questioning of my authenticity also meant that I would have to work much harder than I had initially anticipated to gain their trust. More importantly, I would need to challenge my own assumptions about what it meant to be a Pakistani immigrant in the United States.

After a great deal of perseverance on my part and time spent just "hanging out," eventually many youth established a good rapport with me, though, interestingly, more boys than girls did so. This initially surprised me, because I assumed that I would be able to gain the girls' confidence more easily since we were all women (again, the notion of insiderness was turned on its head); instead, many of the more "traditional" girls were wary of me. The boys, on the other hand, seemed to enjoy the attention from me-a young, female researcher. In this sense, my lack of authenticity (specifically regarding perceived gender roles) was an asset in 
one respect and a barrier in another. Gender and class were therefore important lenses from which to examine the degree of my insiderness as a native researcher.

Among the families, because the men put in long hours in working-class jobs, I was not able to speak with any fathers. One father, a taxi driver, did give me a ride home one day, but it was very difficult to build rapport with him. Here, my gender and age were barriers. Mothers were generally reticent to speak with me at first, but after I managed to get a conversation going, we built an excellent rapport. In fact, all the mothers I spoke with said to me afterward that the experience was enjoyable and not at all what they had expected (given that this was the first time they had ever participated in any sort of research).

Indeed, there were moments when the youth and their families considered me an ally and an insider, and asked me to represent the community. For example, several students asked me to intervene with school staff regarding their poor grades, which they felt were unfair. In these instances, the youth recognized that I had access to valuable social, cultural, and linguistic capital (cf. Bourdieu, 1986): I was a researcher in the school and therefore had access to the teachers (social capital); I had an understanding of the school system (cultural capital); and I spoke English fluently (linguistic capital). These were forms of capital that the youths' families did not necessarily have. In these instances, my lack of authenticity did not matter to the youth.

But there were also times when the youth and their families recognized that I was in fact far removed from their everyday lives; in these instances, my "outsider" status became painfully obvious to me and to them. For example, on one occasion, I went to interview the mother and aunt of one of the focal girls in the study. I asked the women for permission to take their daughter/niece and her friend out for lunch. I was gently reprimanded and told that this was not possible; they had prepared lunch at home and I was welcome to join them. Here, it became clear to me that I did not understand the ramifications of three young women going out 
for lunch in a community where gossip and surveillance of the youth is commonplace (cf. Jacobs, 1998; Subraminian, 2012). As the women told me, it was not the Americans' gaze that they feared; they feared the ethnic community's gaze much more and its ramifications for the "marriageability" of their daughters. While I am familiar with issues around "gossip" in South Asian communities, I was surprised at this. It was an important learning moment and one that forced me to challenge my own beliefs and assumptions.

Both these examples showed that my position on the insider/outsider continuum was in constant flux. However, though I acknowledge the fluidity of my identity, I bear the "the burden of representation" bestowed upon me by those who laud and praise such research, and from the participants themselves, who sometimes asked me to represent them. This burden of representation is further complicated in the current political milieu, where there is a growing interest in Pakistanis and Muslim groups in general, yet little research is available, making any research on the subject more prominent. The act of research itself thus becomes a "burden of representation." I do not want to suggest that writing about one's "native group" is always a burden in a negative sense, but it certainly does position the researcher and the research in a particular way. Thus, a certain responsibility to the community in question becomes attached to the research. It is to the issue of positionality - how one is positioned and how one positions oneself - that I turn to next.

\section{Positionality}

Lila Abu-Lughod (1991) argues that knowledge is not only always partial, it is also always situated (p. 469). This partiality and positionality do not make one's research any less valuable, but they do require recognition. Moreover, as Stuart Hall (1989) suggests, “You have to position yourself somewhere in order to say anything at all" (p. 18). Hence, acknowledging 
that any representation is partial and paying attention to positionality - both one's own position and how one is positioned - is essential to understanding its effects on one's research.

I arrived in the United States as an adult. My participants were primarily youth. Some were born in the United States, others arrived as babies or young children, some arrived during the course of my study. Some were born into citizenship; most were naturalized at the age of seven, eight, or nine; some were permanent residents; others were undocumented. The most salient differences, however, were around socioeconomic class. Pakistani society is deeply divided by class, and these class divisions are replicated within the Pakistani Diaspora in the United States and elsewhere. Beyond class divisions, Pakistan is an ethnically diverse society (Punjabis, Sindhis, Baluchis, and Pashtuns form the four major ethnic groups, although there are others). Moreover, there is religious diversity - not only in terms of majority Muslim and minority others, but also within the Muslim community, where there are sectarian differences (Sunni, Shi'a etc). My own background is one of privilege; I am very aware of my uppermiddle-class background, and I was cognizant of the class divisions within the Pakistani community here in the United States. While I expected to be working with youth who were lower-middle class and working class, I did not realize how little I knew about what it meant to be a working-class Pakistani immigrant, particularly in the post-9/11 context, and how my thinking was laden with assumptions.

The first of my assumptions in my initial research question was around the possibility that Pakistani immigrant youth were engaged in the cultural production of a "new ethnicity" (see Hall, 1992), that of "Pakistani-American." Based on my experiences and interactions with affluent Pakistanis in the United States, I had assumed that the youth I was engaging with would see themselves as Pakistani-Americans, and that this was not a hybrid, in-between identity but a new ethnicity in and of itself. However, as Paul Gilroy (1993) reminds us, 
"Cultural production is not like mixing cocktails" (pp. 54-55). While "Pakistani-American" is a term that is often heard in more affluent Pakistani immigrant circles, a community I am more familiar with, it was hardly ever used by the working-class youth in this study. In fact, the youth who embraced "American-ness" did so at the cost of their "Pakistani-ness" and viceversa. The two could not be reconciled (see Ghaffar-Kucher, 2012).

I had not initially recognized the possibility that my participants would not identify themselves as Pakistan-Americans because in my limited contact with other groups of Pakistani immigrants and my romanticized vision of the United States as the land of opportunity, I had paid scant attention to the structural, societal, and institutional barriers that immigrants in general face simply because these barriers were not visible to me (partially because as someone who came to the Unites States as an adult, I did not understand American racism). As a privileged, western-educated, female Pakistani, I had both the knowledge and the access to forms of capital that are valued in U.S. society. Most of my participants did not have access to these forms of capital. The variation in English proficiency and accents marked the students in particular ways - their particular linguistic competence and capital were not the kind that was valued in U.S. society; they lacked a certain social capital because of the divided Pakistani immigrant community and because their parents did not know how to navigate the school system and could provide them little guidance, or simply did not have time since they worked long hours. Moreover, whereas Pakistani women typically are in subservient positions, here I was as a Pakistani-woman in a position of relative power. Most significant of all, however, the terrorists attacks of 9/11 had resulted in marking individuals and groups like my participants in ways that I could not imagine and that I certainly never or very rarely experienced. They were now seen as non-citizens and outside of the realm of American citizenship, even in instances where the youth were born and raised in the United States (see Ghaffar-Kucher, 2012). 
Again, my lack of understanding (or indeed insider perspective) was evident in my initial research design. I was tired of the way that the growing research on Muslim communities in the United States seemed to frame them as a singular entity in the post-9/11 world - as if all of a sudden Muslims had come into existence. I decided that I wanted my study to talk back to all these people who were framing Muslims as a monolithic group and show the great diversity among Muslims. To do this, I focused on the group I thought I knew best: Pakistani immigrants (in this instance, I was embracing the burden of representation). Irrespective of 9/11, I also was simply interested in the Pakistani immigrant experience as a Pakistani with a reverse migration experience: Although born in Pakistan, my family moved to Hong Kong when I was one-yearold and moved back to Pakistan just before my 12th birthday. I wanted to explore the ways that youth were navigating expectations from multiple worlds and their engagement in the cultural production of their identities. I did not ignore September 11; I just did not want the study to be about September 11. It took me a long time to realize that this was partially because my own experiences post-9/11 were not so life changing and partially because I did not understand the concept of institutional racism at the time. I certainly had my moments; for example, when entering the country at JFK airport only to be told that I had to go into secondary inspection. For someone with brown skin, this is a humiliating experience-you are walked in front of everyone, amid stares, to a windowless side room. But secondary inspection was something I put up with perhaps once a yeariii, my participants went through a sort of secondary inspection - what Sarroub (2002) calls "wanding" (pp. 300-301) - every day of their lives. For them, there was no getting away from September 11-September 11 somehow showed up in their quotidian existence. Thus, my position as a Pakistani immigrant who had not borne the brunt of September 11 affected the way I designed and positioned my research. Fortunately, qualitative research is a living, breathing form, and I was able to change the design and 
questions to explore the issues that became more acute. In the end, September 11 came to center stage (see Ghaffar-Kucher, 2008, 2012, 2014).

But the question remains: How could I possibly have started out on this research thinking that I was an insider to the Pakistani immigrant community when I knew so little about their lives? My lack of knowledge of the community is quite contrary to the critique that I did not have enough distance from community and their experiences. I thought I knew the community, and I did not. My naïveté may simply have been because I was a novice researcher. But I have engaged with many other researchers, both novice and experienced, and I have found that there is not enough critical reflection around native research. Native researchers in particular assume too quickly that they are insiders. Researcher identity and positionality need far more attention.

However, the real issue that I am leading to is that despite all of this critical selfreflection on my part, in the end, people both within and outside the academy view me as an insider because I share a national background with my participants - and this is certainly complicated by race. As Ella Shohat (1995) explains, "representation of an underrepresented group is necessarily within the hermeneutics of domination, overcharged with allegorical significance" (p. 170). Thus, people of color are often seen as representative of an entire group while whites are typically seen as individuals. In other words, people of color bear the burden of representation in a way that white people never have to, and since the academy remains majority white, this perspective continues to thrive. Furthermore, the community also looked to me to represent them in certain instances. Thus, whether I embrace it or not, the burden of representing this community is placed on my shoulders and it is a burden I have to embrace in order to continue to work with the Pakistani immigrant community. Given these expectations, it only makes sense to ask: for whom am I writing? And to whom am I accountable? 


\section{Audience and Accountability}

The issues of audience and accountability are complicated. For whom was I writing this story? Until recently, most native researchers have had to straddle the divide of doing research "there" and writing about it "here" - meaning that their audience is primarily in the Western academy, even though they are writing about people in a land "far away." This is an issue that Ryang (1997) struggled with in discussing her research as a Japanese-born Korean studying Koreans in Japan. She grappled with conducting fieldwork in Korean and/or Japanese and then writing about the experience in English for a Western, English-speaking audience. But in U.S.based immigrant research, I was writing about people here, to be consumed by an audience here, with potential implications for policy here. I was also writing about a group that is frequently covered in the mainstream media but is understudied within U.S. academia. Yet I never asked myself the three sets of questions that I would now ask and would encourage others to ask, in order to be more self-reflective and more importantly, accountable to one's various constituents.

\section{Writing for whom and for what purpose?}

The first set of questions relates directly to audience and purpose: Who is my audience and what is my purpose in this research? Am I interested in being a "cultural broker" and simply mediating, or bringing greater understanding, between two groups (see Scasz, 2001)? Am I embarking on what Tedlock (2005) refers to as a "public" or politically engaged ethnography in which I am striving to address the issues faced by Pakistani immigrants in an effort to serve the community or initiate change in it? Or am I simply telling the story of particular group of immigrants to add to the literature on immigrants? 
On a more personal level, am I writing simply to advance my career in the academy, or am I personally committed to social justice - and can I do both? How do I position myself? Do I write in exclusive peer-reviewed journals, open-access journals, a public blog, or opinion pieces in the newspapers?

\section{Reflecting on the self}

The second set of questions is more about researcher identity. Who am I to tell this story? How does my own history and positionality shape and influence the research? What implications does my position as a Pakistani researcher have for my research? The answers to these sets of questions have significant implications for research design and for writing up the research. The second set, in particular, can completely change the first set.

\section{Accountable to whom?}

This brings me to the final set of questions, which relate to the participants. What reallife implications does my study have for my participants? How do I do them justice? What happens when one's research is "forced" or "invited" into the public eye? How do the answers to these questions change when the research becomes public? The question that was most important for me to consider was: To whom was I accountable?

\section{Responding to my own questions}

When I was writing my dissertation, I had simply hoped that my research would be of value for its own sake and would bring greater understanding of a particular Muslim community by contributing to the growing literature on Muslim immigrant youth. Beyond that, I had not thought of the real life consequences of this research for my participants, or for me. For my participants - who were young teens at the time of the research - I had not anticipated the day when they might download and read my dissertation and what it would be like for 
them to read what I had written (an issue that we have not really come to terms with in academia). For myself, I did not understand the implications of being a minority, writing within the Western (majority white) academy, and writing to be read by a primarily Western audience. The crisis of representation faced by qualitative researchers becomes especially acute when you are writing for a community to which you feel a certain level of belonging, even if you are only on the periphery. Indeed, it becomes a burden of representation.

Having thought about the myriad issues raised in this article for a few years now, I now understand what it means to be a minority voice in the academy and the power that this in fact gives me. I understand better my own positionality and what it means to carry the burden of representation, and also the possibilities that this burden provides. Since my voice is one of the few (at this time) that speaks to the experiences of a subset of Muslim immigrant youth, rather than shy away from my research because of the skepticism on one hand and pressure to represent on the other, I have to "speak louder". I would be dishonest if I were to say that I do not write for myself and for advancing my career, but part of writing for oneself is to be able to gain prominence so that what you write is amplified and heard.

Thus, while generating theory and writing up research in journals is important and necessary to gain prominence and move forward in my academic career, to be truly heard, I believe I have to make my work accessible by writing for a wider audience and by ensuring that my work is freely available (e.g., through Scholarly Commons, Academia.edu). More importantly, I know that I have to bring my work into the public arena by writing opinion pieces in newspapers, being available for interviews, being active on social media, and engaging in other perhaps "less academic" pursuits. Even though this kind of public engagement takes time and commitment and is not yet valued by many in academia (it certainly does not "count" as scholarly output), it is worth doing. I would not go as far as saying that I am an activist 
researcher or that I am politically engaged (and I greatly admire those who are) but I do believe my work must have some value to the public - not just to the academic community - and that is what will hold me accountable to my participants. Writing op-eds is a particularly powerful way to engage the public in scholarly discourse and also provides an opportunity for participants to hear their stories re-told and to participate and react to the telling of their stories. Through public engagement, not only do we become more accountable in our work, our work becomes more influential because it is not confined to scholarly discourse but becomes part of public discussion. In this way, the potential for action and activism is there-even if the researcher herself is not directly part of that activism.

\section{Conclusion: Embracing the Burden of Representation}

I began this reflection by drawing on the reactions that a person like me - a woman of color from an immigrant background - faces when trying to present her research to a wide audience. On the one hand, native research is criticized for being "biased," while on the other hand, it is lauded for bringing greater nuance to research. Both perspectives take for granted what it means to be a native researcher. As such, this essay is a call for greater and more indepth self-reflection in "insider" research - irrespective of epistemology and ontology or where one stands and moves along the native/non-native continuum. As Lopez (2002) argues, “The race, gender, and class location of the researcher and participants always shape the framing of an issue, the questions asked, and the dynamics of the interview, regardless of whether one utilizes qualitative or quantitative data or a combination thereof" (p. 11, emphasis in original). Native research, then, must neither be overly romanticized nor overly criticized; indeed, native research has much to offer, but there must be greater recognition of its shifting nature of the native researcher's insider/outsider status. Researchers in general must acknowledge and 
discuss how they navigated the insider-outsider borders, as well as other attributes (e.g., gender, ethnicity, language, religion, sexuality), and the ways in which these attributes influenced the research design and writing.

Before embarking on any research - particularly in a politically charged field such as immigration - we need to think about our positionality, why we are engaging in the work, the audience with whom we will share our work, and the implications of this work for our participants. The cost of failing to pay attention to such issues is extremely high, as it can not only compromise the integrity of our research but may also impact the lives of our research participants in unexpected ways. Because we live in an era in which information is at everyone's fingertips, we must give far more consideration to issues of accountability. For example, what are the implications if the participants of a study download the research and read what the researcher has written about their community? Even if identities have been masked, participants may read the work differently than it is intended (this goes back to the crisis of representation that qualitative researchers face). It is only by thinking about the kinds of questions that I pose in this article that we can be more accountable to our participants and help ensure that we do a better job in our research. These considerations are especially important for the native researcher given the burden of representation that comes with this identity. Indeed, for the native researcher, the burden of representation is sometimes a heavy one, but it is a burden worth bearing.

\section{Endnotes}

i The title of this article, "Writing culture; inscribing lives" is inspired by two texts: The first, James Clifford and George Marcus' classic anthology (1986), Writing Culture: The Poetics and Politics of Ethnography, in which the volume's authors reflected on the politics and ethics of ethnographic research, particularly in a globalizing world where the ethnographic enterprise is contestable by the very people it seeks to represent. The second inspiration is Laurel 
Richardson's (1990) book, Writing Strategies: Reaching Diverse Audiences, in which she argues, "No textual staging is ever innocent. We are always inscribing values in our writing. It is unavoidable" (p. 12). Together, these texts capture the heart of this article, which seeks to explore the implications of our identities on the on how we conduct and write our research.

ii I refer to all the youth in my study as Pakistani-American irrespective of their citizenship status.

iii Had I been male, this most certainly would have been different given the PATRIOT Act, which required non-citizen males from 25 countries (mostly Muslim-majority) to formally register with the Bureau of Immigration and Customs Enforcement when entering and leaving the country.

\section{References}

Abu-Lughod, Lila (1991). Writing against culture. In R. G. Fox (Ed.), Recapturing anthropology: Working in the present (pp. 137-162). Santa Fe, NM: School of American Research Press. Abu El-Haj, Thea Renda (2007). “I was born here but my home it's not here": Educating for democratic citizenship in an era of transnational migration and global conflict. Harvard Educational Review 77 (3): 285-316.

Baldonado, Marie. (1996). Representation. Retrieved on June 20, 2010 from https:/ / scholarblogs.emory.edu/postcolonialstudies/2014/06/21/representation/

Brayboy, B. Mck. (2000). The Indian and the Researcher: Tales from the Field. International Journal of Qualitative Studies in Education, 13(4), 415-426.

Bourdieu, Pierre (1986). The forms of capital. In J. Richardson (Ed.), Handbook of theory and research for the sociology of education (pp. 241-258). New York: NY: Greenwood Press.

Clifford, James \& Marcus, George (1986) (Eds.). “Writing Culture” The Poetics and Politics of Ethnography. University of California Press

Ghaffar-Kucher, A. Writing culture; inscribing lives. A reflective treatise on the burden of representation in native research. International Journal of Qualitative Studies in Education. 2014 
Collins, Patrica Hill (2000). Black Feminist Thought. New York: Routledge

Delgado Bernal, D. (1998). Using a Chicana feminist epistemology in educational research. Harvard Educational Review, 68(4)

Delgado-Gaitan, C. (1993). Researching change and changing the researcher. Harvard Educational Review 63(4), 389-411

Denzin, N. K., \& Lincoln, Y. S. (1998). Introduction: The discipline and practice of qualitative research. In N. K. Denzin \& Y. S. Lincoln (Eds). The Landscape of Qualitative Research. Thousand Oaks, CA: Sage

Denzin, Norman, K., \& Lincoln, Yvonna, S. (1994). Introduction. The discipline and practice of qualitative research (pp. 1-32). In Norman K. Denzin, Yvonna S. Lincoln (Eds). The SAGE handbook of qualitative research. (3 ${ }^{\text {rd }}$ edition). Thousand Oaks, CA: Sage.

Foley, Douglas. E. (2008). Reconceptualizing ethnicity and educational achievement. In N. Shimahara, I. Z. Holowinsky, S. Tomlinson-Clarke (Eds). Ethnicity, race, and nationality in education: A global perspective. Taylor Francis.

Foley, Douglas E., Levinson, Bradley A., and Hurtig, Janise (2000) Chapter 2: Anthropology Goes Inside: The New Educational Ethnography of Ethnicity and Gender. Review of Research in Education 25(37)

Ghaffar-Kucher, Ameena (2008). The (Mis)Education of Pakistani Immigrant Youth. Doctoral dissertation. Teachers College, Columbia University. PROQUEST

Ghaffar-Kucher, Ameena (2012). The Religification of Pakistani-American Youth. American Educational Research Journal, 49(1)

Ghaffar-Kucher, Ameena (2014). "Narrow-minded and oppressive" or a "superior culture"? Implications of Divergent Representations of Islam for Pakistani-American Youth. Race Ethnicity and Education. DOI:10.1080/13613324.2014.889111 
Gilroy, Paul (1993) The Black Atlantic: Modernity and Double Consciousness, London: Routledge. Hall, Stuart (1989). Ethnicity: Identity and Difference.. In Randy Bass and JoyYoung (Eds). Beyond Borders. Houghton Mifflin. pp. 228-4

Hall, Stuart (1992). New Ethnicities. In A. Rattansi and J. Donald (Eds.) Race, Culture and Difference. Sage Publications

Hastrup, Kirsten (1995). A passage to anthropology: Between experience and theory. Routledge.

Jacobson, J. (1998). Islam in Transition: Religion and Identity among British Pakistani youth. London: Routledge.

Jacobs-Huey, Lanita (2002). The natives are gazing and talking back: Reviewing the problematics of positionality, voice, and accountability among "native" anthropologists. American Anthropologist. 104 (3), pp. 791-804.

Kluckhohn, Klyde (1949). Mirror for man. The relation of anthropology to modern life. New York: McGraw Hill.

Lincoln, Y.S., Lynham, S. A., and Guba, E. G. (2011). Paradigmatic controversies, contradictions, and emerging confluences, resvisited. In N. K. Denzin \& Y. S. Lincoln (Eds). The Sage Handbook of Qualitative Research (4th Ed). Thousand Oaks, CA: Sage.

Lopez, Nancy (2002). Hopeful girls, troubled boys. Race and gender disparity in urban education. New York: Routledge

Maira, Sunaina (2002). Desis in the house. Indian American youth culture in New York City. Philadelphia PA: Temple University Press.

Maira, Sunaina (2009). Missing. Youth, Citizenship and Empire after 9/11. Duke University Press. Mendoza-Denton, Norma. (2008). Homegirls: Language and Cultural Practice Among Latina Youth Gangs. Jonh Wiley \& Sons.

Narayan, Kirin (1993). How native is a "native" anthropologist? American Anthropologist, 95, 28. 
Ngo, Bic (2010). Unresolved Identities: Discourse, Ambivalence, and Urban Immigrant Students. SUNY Press.

Ong, Aiwah. (1995). Women out of China: Traveling tales and traveling theories in postcolonial feminism. In R. Behar\& D. Gordon (Eds.),Women writing culture (pp.350-372). Berkeley: University of California Press

Perry, P. (2001). White Means Never Having to Say You're Ethnic. White Youth and the Construction of "Cultureless" Identities. Journal of Contemporary Ethnography, 30(1) pp. 56-91

Richardson, Laural (1990). Writing strategies: Reaching diverse audiences. Thousand Oaks, CA: Sage.

Ryang, Sonia (1997). Native anthropology and other problems. Dialectical Anthropology, pp. 23-49 Sarroub, Loukia K. (2002). From neologisms to social practice: An analysis of the wanding of America. Anthropology \& Education Quarterly 33 (3), 297-307

Shankar, Shalini (2008). Desi Land: Teen Culture, Class, and Success in Silicon Valley. Duke University Press.

Shohat, Ella. (1995). The Struggle over Representation: Casting, Coalitions, and the Politics of Identification." In Roman de la Campa, E. Ann Kaplan and Michael Sprinkler (Eds), Late Imperial Culture. New York: Verso.

Stanton-Salazar, Ricardo (2001). Manufacturing Hope and Despair: The School and Kin Support Networks of US-Mexican Youth. New York: Teachers College Press

Subramanian, Mathangi. (2012). Gossip, drama, and technology: How South Asian American young women negotiate gender on and offline. Gender and Education, Advance online publication. DOI 10.1080/09540254.2012.746647 
Szasz, Margaret Connell (2001). Between Indian and White worlds: The cultural broker. (2nd edition) Norman, OK: Red River Press.

Tagg, John (1988). The Burden of Representation: Essays on Photographies and Histories. University of Minnesota Press.

Tedlock, Barbera (2005). The observation of participation and the emergence of public ethnography. (467-482). In Norman K. Denzin, Yvonna S. Lincoln (Eds.) The SAGE handbook of qualitative research. (3 ${ }^{\text {rd }}$ edition). Thousand Oaks, CA: Sage. Valenzuela, Angela. (1999). Subtractive Schooling: US Mexican Youth and the Politics of Caring. New York: State University of New York.

Villenas, Sofia (2001). Latina mothers and small-town racisms: Creating narratives of dignity and moral education in North Carolina. Anthropology and Education Quarterly, 32(1), pp. $3-28$.

Villanas, Sofia (1996). The colonizer/colonized Chicana ethnographer: Identity, marginalization, and co-optation in the field. Harvard Educational Review, 66(4), pp. 711-731.

Zhou, Min (1992). Chinatown: The Socioeconomic Potential of an Urban Enclave. Philadelphia, PA: Temple University Press.

\footnotetext{
i The title of this article, "Writing culture; inscribing lives" is inspired by two texts: The first, James Clifford and George Marcus' classic anthology (1986), Writing Culture: The Poetics and Politics of Ethnography, in which the volume's authors reflected on the politics and ethics of ethnographic research, particularly in a globalizing world where the ethnographic enterprise is contestable by the very people it seeks to represent. The second inspiration is Laurel Richardson's (1990) book, Writing Strategies: Reaching Diverse Audiences, in which she argues, "No textual staging is ever innocent. We are always inscribing values in our writing. It is unavoidable" (p. 12). Together, these texts capture the heart of this article, which seeks to explore the implications of our identities on the on how we conduct and write our research.

ii I refer to all the youth in my study as Pakistani-American irrespective of their citizenship status. iii Had I been male, this most certainly would have been different given the PATRIOT Act, which required non-citizen males from 25 countries (mostly Muslim-majority) to formally register with the Bureau of Immigration and Customs Enforcement when entering and leaving the country.
} 